\section{En mektig dåre}

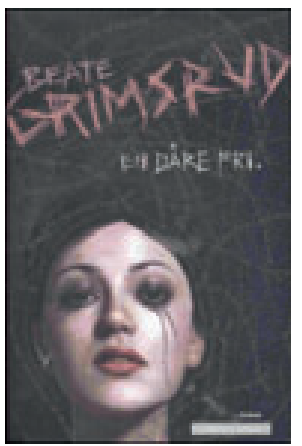

Beate Grimsrud

510 s. Oslo: Cappelen Damm, 2010

Pris NOK 369

ISBN 978-82-02-33600-4

En dåre fri var nominert til Nordisk råds litteraturpris 2011. Den er en skjønnlitterær roman, men kan også leses som en selvbiografi. Og den kan leses med faglige briller. «Det kan bli mye kunst av forferdelige opplevelser,» sier fortelleren, «det er bare å stå på». Og det har hun sannelig også gjort. Her er hele psykiatrien samlet i én person. Her følger vi jeg-personens psykiske problemfortelling fra da hun var seks år og videre frem gjennom år med dysfunksjonelt familiesamspill, manifeste symptomer på dissosiasjonsforstyrrelse, depersonalisering, derealisasjonsopplevelser, grandiositet, selvskading, rusmisbruk, kjønnsidentitetsforvirring, svaksynthet - og etter hvert årelange psykotiske faser som behandles med innleggelser, psykofarmaka, depotmedikasjon, beltelegging, psykoterapi (psykodynamisk, kognitiv) til hun er 39 år. Innimellom er hun en stjerne på fotballaget og i bokseringen, og i gode perioder skriver hun vellykkede bøker og lager god film. Alt er fortalt $i$ et korthugget, usentimentalt språk som samtidig formidler lidelse og desperasjon - men også triumf. Gjennom hele historien er fortelleren - eller rettere sagt minst én av de fire personene (tre menn) som fortelleren røper at hun kan skifte mellom, mektigere og mer suveren enn alle som er rundt av mulige behandlere. Det er også disse mektige personene i henne (Erik, prins Eugen), som oppfordrer til vold og utagering og til å sabotere velmente terapeuters forsøk.

Vanligvis vil slike forfattere legge vekten på hvor forferdelig dumme eller brutale eller umenneskelige terapeutene er. Ikke denne forfatteren. Behandlerne skildres med forståelse og empati, som tålmodige og velmenende, men samtidig som temmelig hjelpeløse hjelpere. De prøver å få til kontakt og samarbeid, men de har motstandere i pasienten som alltid er mektigere og som de ikke klarer å komme $i$ en forpliktende dialog med. I det hele tatt viser boken svært autentisk hvor stor avstanden kan være mellom en pasients virkelighet og behandlernes, og hvordan en tilsynelatende svært syk, men samtidig ressursrik pasient kan slåss for livet for å slippe å samle seg til én eneste person som må stå for sine tanker og handlinger fullt ut.

Boken får også frem hvor ødeleggende det kan være når man endelig har fått til et hjelpeopplegg som en slik pasient profitterer på, og så skal alt omorganiseres nok en gang. Helt på slutten står det: «Nå har jeg det perfekt for første gang i psykiatrien. Nå har jeg mange kontaktpersoner, og kan lett få tak i noen. Jeg bor hjemme. Jeg kommer til behandlingen når jeg vil og behøver, og spiser og prater litt. Jeg treffer de samme kontaktpersonene når jeg er innlagt som når jeg er ute. De kjenner stemmene mine og min måte å være på. De kan roe meg og støtte meg når det begynner å skli utfor. Det er stor forskjell på en telefonsamtale eller et møte med hvem som helst og et møte med noen man kjenner godt. Nå forsvinner de. Nå skal alt forandres.» (s. 430). Hvis du er en psykiater som sliter med følelsen av håpløshet og hjelpeløshet i forhold til dårlige pasienter, er ikke dette en bok som gir deg mer håp. Hvis du er en psykiater som vil vite mer om hva som driver slike pasienter til å oppføre seg som de gjør, ja da tror jeg du vil være litt klokere etter å ha lest denne.

\section{Per Vaglum}

Avdeling for medisinske atferdsfag

Institutt for medisinske basalfag

Universitetet i Oslo

\section{Fortellinger om galskap}

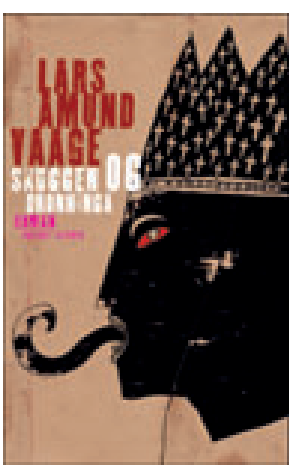

Lars Amund Vaage

Skuggen og dronninga

152 s. Oslo: Forlaget Oktober, 2010

Pris NOK 349

ISBN 978-82-495-0400-8

Lars Amund Vaage (f. 1952) er en prisbelønt forfatter, og dette er hans tiende roman. På omslaget kan vi lese: «Han har mellom anna mottatt Kritikarprisen, Aschehougprisen, Gyldendalprisen, Doblougprisen og P2-lyttaranes romanpris, og vore nominert til Nordisk Råds litteraturpris.» Ikke dårlig! Men hvor mange har hørt om ham? Lest bøkene hans? Riktignok skriver han på nynorsk, men det har aldri hindret en Kjartan Fløgstad eller Edvard Hoem fra å innta bestselgerlistene. Vaage derimot, er en såkalt forfatternes forfatter. Lovprist av kolleger, men i liten grad lest og solgt. Lavmælt er et ord som går igjen i anmeldelsene. Og på norsk er det en hedersbetegnelse, ofte forbundet med eksklusivitet.

Hva handler romanen om? Vel. Ettersom Tidsskriftet vil anmelde den, kan vi anta at den handler om sykdom - eller har en lege som hovedperson. Og det stemmer. Begge deler. Fortelleren Mikal er lege, bosatt i Oslo, men oppvokst på et lite industristed på Vestlandet. Historien er inndelt i fem kapitler og veksler mellom nåtid og fortid. Mikal har restaurert en hytte i barndomsbygda, og innledningsvis er han og samboeren Inger på vei for å innvie den. Hoveddelen av romanen handler imidlertid om erindringer fra Mikals barndom. Mikal er fortelleren, men hovedpersonene er Sara, bestemoren hans, og sønnen hennes Sam.

Romanen er en historie om galskap (og jeg bruker bevisst Vaages terminologi). Sara er gal, psykotisk, hører stemmer og ser syner, er en bortført prinsesse, fyrstinne og dronning. Hun raver rundt i nabolaget, synger og snakker med seg selv. Og lager julaften i september. Sam - som egentlig heter Samson - er taus, storvokst og tilbakestående, og blir i tillegg like gal som moren. Både mor og sønn tilbringer mesteparten av livet på «sinnssjukehuset». Der blir de utsatt for inhumane, nedverdigende og brutale behandlingsmetoder. De legges i reimer. Dopes ned. Og brytes ned. Sam er $\mathrm{i}$ årevis innesperret i asylets kjeller, får utallige elektrosjokk og ender som en zombie. Sara pasifiseres og sløves, men forblir i sin psykotiske forestillingsverden.

«Fargesterkt og smertefullt om den nådeløse psykiatrien» var overskriften til Dagbladets anmelder. Klassekampen kåret boken til årets beste, og skrev: «Vaage oppsøkjer galskapen og visar lesaren at det ikkje handlar om sjuke individ, men om eit ekskluderande samfunn.» Nå ja. Så enkelt kan det kanskje sies. Og så mye om den politiske agenda. Men la oss gå utenom den. For jeg tror at Vaage ønsker å ta opp et annet problem: galskap (hans ord) som symbol og virkelighet, og derfor som en utfordring til vår oppfatning av det menneskelige. Gjennom tidene har vi sett forskjellig på de gale; som kontaktpunkter med gudene, som skremmende avvikere eller som svært syke. Vi har vekselvis æret dem, frosset dem ut og forsøkt å helbrede dem.

Hvis dette skulle være prosjektet, lykkes han da? Jeg tror ikke det. Ikke fordi han ikke har virkemidlene. Vaage skriver stramt kompositorisk. Språket er stilrent, poetisk og metaforisk. De høye terningkastene er velfortjent. Han skulle kunne skape bilder som både rører og påvirker oss. Men han gjør ikke det.

Det er to grunner. Den første er generell. Galskap som fiksjon er krevende fordi det er oppbrukt og utvannet. Det er noe banalt over forfatteres - Vaage iberegnet - umettelige fascinasjon av galskap; 